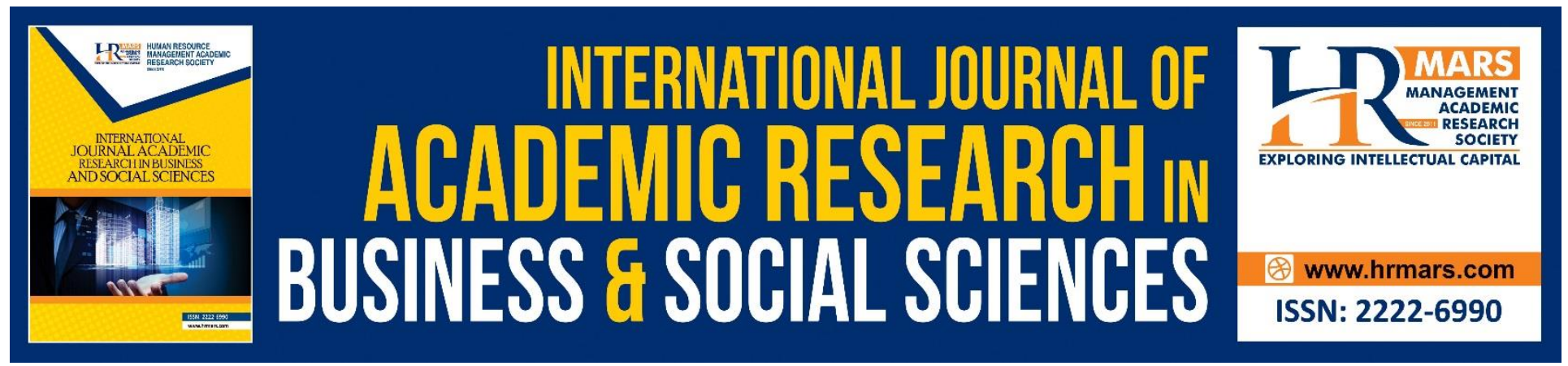

\title{
Evaluation of the Quality of Educational Services at the University of Mohammed bin Ali Al-Sanussi (Libya)
}

Marwan Ibrahim Alfadhli, Khaled Abed-Alwahed Boshnaf, Salim Sultan Abdulsalam, Nadia Rafalla Elhaddad

To Link this Article: http://dx.doi.org/10.6007/IJARBSS/v9-i3/5622

DOI: $\quad 10.6007 /$ IJARBSS/v9-i3/5622

Received: 09 Feb 2019, Revised: 24 Feb 2019, Accepted: 12 March 2019

Published Online: 17 March 2019

In-Text Citation: (Alfadhli, Boshnaf, Abdulsalam, \& Elhaddad, 2019)

To Cite this Article: Alfadhli, M. I., Boshnaf, K. A.-A., Abdulsalam, S. S., \& Elhaddad, N. R. (2019). Evaluation of the Quality of Educational Services at the University of Mohammed bin Ali Al-Sanussi (Libya). International Journal of Academic Research in Business and Social Sciences, 9(3), 1-15.

Copyright: (C) 2019 The Author(s)

Published by Human Resource Management Academic Research Society (www.hrmars.com)

This article is published under the Creative Commons Attribution (CC BY 4.0) license. Anyone may reproduce, distribute, translate and create derivative works of this article (for both commercial and non-commercial purposes), subject to full attribution to the original publication and authors. The full terms of this license may be seen

at: $\underline{\text { http://creativecommons.org/licences/by/4.0/legalcode }}$

Vol. 9, No. 3, 2019, Pg. 1 - 15

http://hrmars.com/index.php/pages/detail/IJARBSS

JOURNAL HOMEPAGE

Full Terms \& Conditions of access and use can be found at http://hrmars.com/index.php/pages/detail/publication-ethics 


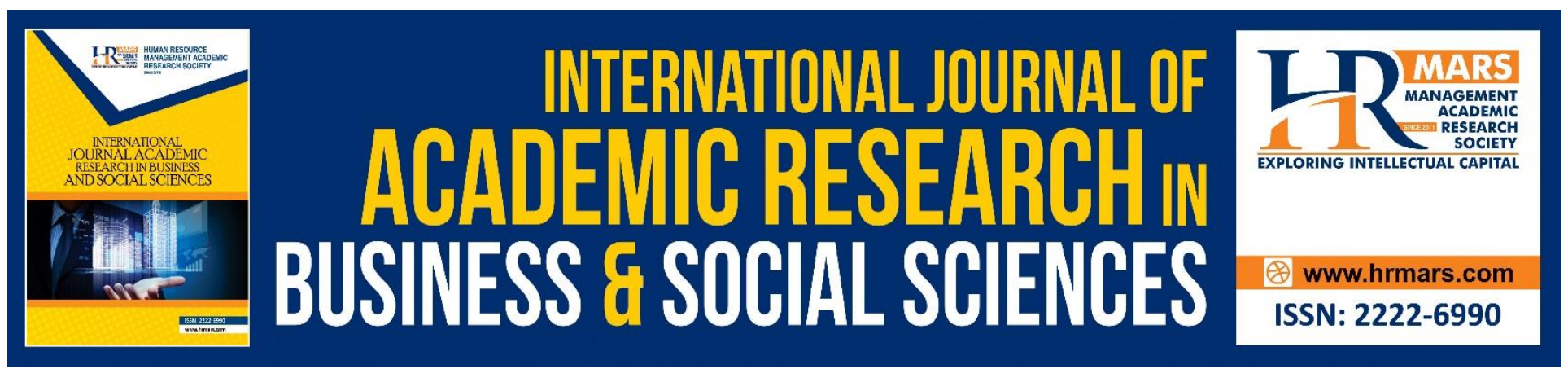

\title{
Evaluation of the Quality of Educational Services at the University of Mohammed bin Ali Al-Sanussi (Libya)
}

\author{
Marwan Ibrahim Alfadhli \\ Financial Accountant at Elmerqib University \\ Email: marwanalfadhli1988@gmail.com
}

Khaled Abed-Alwahed Boshnaf

Faculty member at the University of Mohammed bin Ali Sanoussi

Salim Sultan Abdulsalam

Faculty member at Faculty of Economics- University of Mohammed bin Ali Sanoussi

Nadia Rafalla Elhaddad

Faculty member at Faculty of Economics- Benghazi University

\begin{abstract}
The purpose of this research is to identify the quality of educational services provided by the University of Mohammed Bin Ali Al-Sanussi from the point of view of the members through their opinions and evaluation of the quality of educational services at the University. The researchers used the statistical analysis program (SPSS) and the descriptive analysis, such as arithmetic mean and standard deviation. To measure the relationship between the variables, the researchers used the correlation coefficient (Pearson Correlation). The research found that there is a statistically significant relationship between independent and dependent research variables. The classrooms are equipped and easily accessible. There are also programs to new students, familiarize them with university laws, and facilitate communication between students, staff and faculty members. The researchers recommended working on the development and continuous improvement of medical services, providing special facilities for people with special needs and qualifying students through their participation in conferences, scientific seminars and workshops, moreover, urging students to submit a presentation at the end of each semester.
\end{abstract}

Keywords: Quality, Educational Services, Mohamed Ben Ali Al-Sanussi, and Libya. 


\section{Introduction}

The quality of educational services in the present era is of interest to all educational institutions around the world, both developed and developing, especially after the revolution of technology and globalization that has swept the world (Hudaibi \& Qudhwa, 2009, p. 93). In fact, the development and knowledge of the Information Society is a constant question, development and innovation in education have made it inevitable (Ereş \& Clothey, 2013, p 6).

Where education is witnessing locally, internationally and regionally many attempts to improve and develop it. Recently, attention has been increased to the quality of educational services offered by universities, both public and private, where there are some problems that prevent the performance of these services; the development of the quality of educational services in universities has become a necessary and essential for all universities (Salhi \& Jaballah, 2016, p. 60). It is a proven fact that the quality of educational services plays an important role in achieving economic development. Therefore, the quality of educational services are consider as one of the main topics that raise the interest of those interested in education and development, to reach graduates that can contribute to the achievement of economic development (Ajmi \& Al-Tuwaijri, 2016, p. 138).

The quality education services have emerged as one of the most important services in the current era, and the need of all members of universities to achieve a high level of growth and achieve the goals with efficiency and effectiveness in the scientific side and access to outputs characterized by excellence and knowledge to meet the wishes of society (Zaki, 2016, p. 2).

Therefore, quality is the most important factor in global competition, organizations must deliver highquality outputs to survive and achieve goals in the labor market, because educational and research services are one of the most important areas of service in society, especially those provided by universities and institutes of higher education, which play an integral role in the development of societies, therefore necessary to continue to concern attention to improving the quality of education and research services (Gilavand, Fatahiasl \& Majd, 2017, P 188).

\section{Research Problem}

Based on the above, we find that the quality of educational services receive more attention at the international and regional levels of educational institutions such as universities, higher institutes and research centers to contribute to the improvement and development of the outputs of the educational process to keep pace with technical and technological progress. Libyan public and private universities are keen to provide educational services efficiently and effectively; to meet the needs of their beneficiaries as an attempt to improve and develop continuously, Through the review of the report of the visits to the quality offices of Libyan government universities issued by the National Center for Quality Assurance and Performance Assessment in 2013, Found many challenges that hinder the improvement and development of teaching and learning processes, including: The difficulty of communication and communication between departments, poor qualification and efficiency of human elements, not involving the parties to the educational process (staff, students and faculty members) and considered them partners in the success of quality, and Weak communication at the level of quality in colleges and scientific departments (Report of the Quality Assurance Center). 
Perhaps the University of Mohammed bin Ali Al-Sanussi among those universities that aspire to serve the society and economy of the country, especially that it includes many students, staff and faculty members in the various departments, colleges and scientific departments, In order to promote these society categories and contribute to building the quality of the educational service, it must be integrated and intensified to achieve its goal.

Based on the above, the main question this research is to know: What is the level of quality of educational services at the University of Mohammed bin Ali Al-Sanussi?

To answer the main question, the following sub-questions were asked:

- Is there a relationship between the quality of facilities at the university and the quality of educational services at the University of Mohammed bin Ali Al-Sanussi?

- Is there a relationship between the level of qualification at the university and the quality of educational services at the University of Mohammed bin Ali Al-Sanussi?

- Is there a relationship between ease of communication within the university and the quality of educational services at the University of Mohammed bin Ali Al-Sanussi?

\section{Research Objectives}

The aim of this research is to find out whether the educational services offered by the University of Mohammed Bin Ali Al-Sanussi are of high quality and efficiency by identifying the views of the beneficiaries of students, staff and faculty members, and thus aims to achieve the following points:

- Know the quality of the services provided by the university to its beneficiaries this will be done through the views of students, staff and faculty members.

- Identify the relationship between the quality of facilities at the University of Mohammed bin Ali Al-Sanussi and the quality of educational services.

- Know the relationship between the level of qualification at the University of Mohammed bin Ali Al-Sanussi and the quality of educational services.

- Examine the relationship between ease of communication at the University of Mohammed bin Ali Al-Sanussi and the quality of educational services.

\section{Research Importance}

The importance of research comes from the importance of the quality of educational services within universities and research centers, and because of the specificity of the university and its various Specializations they offer, it is witnessing the influx of students and faculty members from all over Libya. Therefore, the educational services provided to them must be efficient and high quality. Also, the importance of the research is that the researchers are Interested for the quality programs and their guarantee, and that one of them works as a lecturer at the university.

\section{Research Hypotheses}

In order to achieve the research objectives and to answer the questions, the following hypotheses were formulated:

- There is no statistically significant relationship between the quality of facilities within the University of Mohammed bin Ali Al-Sanussi and the quality of educational services. 
- There is no statistically significant relationship between the Level of qualification within the University of Mohammed bin Ali Al-Sanussi and the quality of educational services.

- There is no statistically significant relationship between the ease of communication within the University of Mohammed bin Ali Al-Sanussi and the quality of educational services.

\section{Search Variables}

Independent Variables Dependent Variables

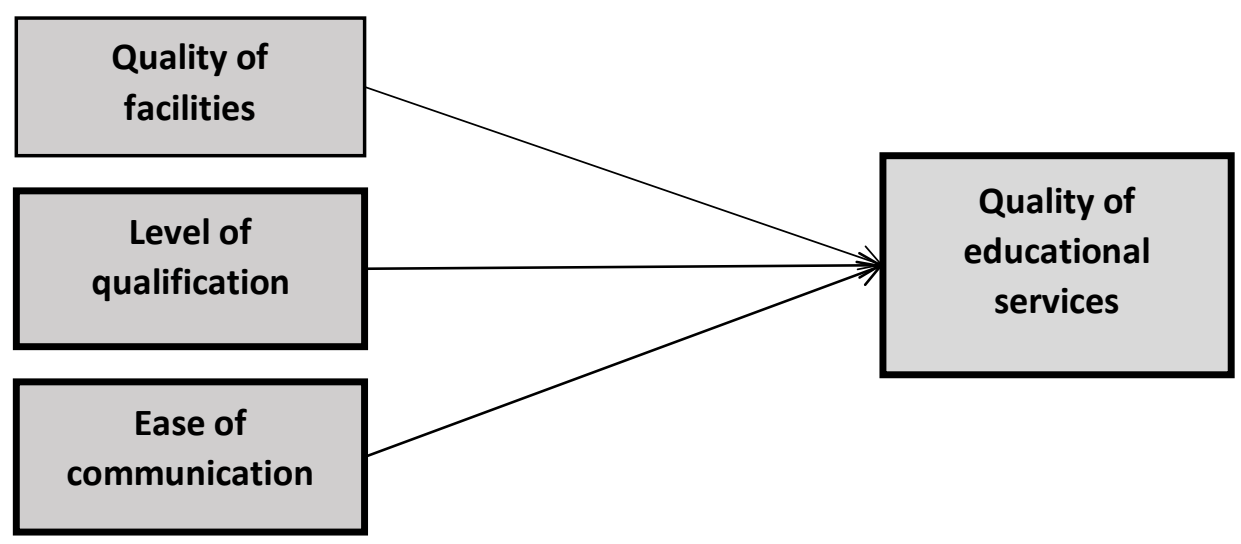

Figure 1: Shows the Search Variables

\section{Literature Review}

Study of Abdelkader (2016). The aim of the study was to measure the students' awareness of the quality of the educational service at Taif University in Al-Kharamah by recognizing the quality of the educational service in the branch and its levels of performance, and identifying the differences in the moral levels of quality according to their variables Demographics, A questionnaire was prepared, which included 17 variables to measure the quality of educational service in the branch, the questionnaires were distributed at the sixth and eighth levels at the bachelor's and fourth-level diplomas. The study found that the students have a full understanding of the components of the quality of the educational service, as well as the lack of differences in the performance levels of the quality variables of educational service in the branch, and the study showed no significant differences of statistical levels of educational service provided by the branch according to their demographic variables combined, Statistical significance of the two components of the behavior of lecturers outside the classrooms, and follow up academic guidance according to the variable specialization.

Study of Salhi \& Jaballah. (2016). Entitled measuring the quality of educational services at the Faculty of Economics and Political Science at the University of Misurata from the point of view of students. The study aimed to identify the level of quality of educational service provided by the Faculty of Economics and Political Science Misurata from the point of view of students of scientific departments, the study used the analytical descriptive method. In addition, the theoretical literature and previous 
studies were reviewed. A random sample of 345 individuals was selected, a questionnaire consisting of five dimensions (reliability, responsiveness, safety, empathy, concrete) was designed to identify deficiencies and strengths in the quality of educational services provided, A number of statistical methods were used to test the hypothesis of the study, use both of the sign TEST for one sample, the WILCOXO test to test two samples and the KRUSKAL test to test more than two samples. The study found that the quality of educational services according to the dimensions of reliability, safety, empathy, and concrete were limited and medium. As for the dimension of response, the quality level was weak, The study also showed significant differences in the quality of educational service provided to the gender variable. There are also no statistically significant differences in the level of quality of educational services used by the variables of the scientific department and the enrollment status.

Shuaibi \& al-Shahrani study (2014). Entitled Assessment of the quality of educational services at King Khalid University from the perspective of students. The study aimed to identify the students' assessment of the quality of educational services at King Khalid University and identify the strengths and weaknesses in them, the study used the descriptive and analytical method, based on the HEDPERF scale after adjusting it in accordance with the Saudi environment. The study sample was (776) Students were selected in a random sampling method. The study found that the students' assessment of the quality of educational services was neutral in all its dimensions, the results indicate that there is no difference between the views of students according to the gender variable, this contrasts with the views of the students regarding (type of college, age, level of study, college, colleges).

Samadi \& Foroozanfar. (2014) aimed at assessing the qualitative gap of educational services in the Faculty of Medical Sciences Nishapur from the point of view of students using the tool SERVOVAL, data were collected using the questionnaire, which was distributed to 199 students to assess service dimensions (quality assurance, response, empathy, reliability). The data was analyzed using SPSS. A negative quality gap was observed in the concrete dimensions there were statistically significant differences between the perception and expectation of students in all dimensions. The results showed that there is a noticeable gap between the expectations of the students and what they have already received from the educational service and therefore the improvement is required in all dimensions.

Eres \& Clothey (2013) perceived determining the quality of educational service among Drexel University students and students of Gazi University. The study included the students of the final year studying at Drexel University 101 American students and 250 Turkey students at the University of Ghazi, by analyzing the data, it was found that Drexel University students are satisfied with the quality of the educational service, while the students of Gazi University are only partly satisfied, and the students' opinions on the sub-dimensions show the difference between the two universities, especially the quality of faculty members, which is an important factor affecting the quality of educational service. According to the results, the most important elements of quality of service (efficiency, readiness, safety, reliability and ability to express), which call for further discussions, research and studies in this area. 
INTERNATIONAL JOURNAL OF ACADEMIC RESEARCH IN BUSINESS AND SOCIAL SCIENCES

Vol. 9, No. 3, March, 2019, E-ISSN: 222 2-6990 ¿ 2019 HRMARS

\section{Research Methodology}

Research methodology is considered the cornerstone of the researcher to reach the results sought, and is the way to solve the problem of research, in addition to being the science on which to rely on how to conduct research. The research community for this paper is composed of all those who belong to the University of Mohammed Bin Ali Al-Sanussi in the Libyan, where the research community consists of students, faculty members and staff of the university as follows:

Table 1: shows the total number of the research community

\begin{tabular}{|c|c|}
\hline & the number \\
\hline students & 3160 \\
\hline faculty members & 250 \\
\hline staff & 500 \\
\hline Total & $\mathbf{3 9 1 0}$ \\
\hline
\end{tabular}

\section{The Research Sample}

The researchers relied on a table (Krejcie \& Morgan, 1970) In order to choose the sample number for the collection of search data were as follows:

Table 2: shows the sample of the research

\begin{tabular}{|c|c|}
\hline & the number \\
\hline students & 342 \\
\hline faculty members & 152 \\
\hline staff & 217 \\
\hline Total & $\mathbf{7 1 1}$ \\
\hline
\end{tabular}

According to the previous data, the total number of questionnaires distributed was 711 , retrieved 650 questionnaires, 7 were missing, 9 were excluded for non-compliance, and the remaining 634 were distributed and subjected to analysis. The Likert scale was used to collect data.

\section{Reliability and Consistency of the Questionnaire}

The researchers formulated the questionnaire after reviewing the previous studies and then they were arbitrated before the interested, specialists and experienced in the field of quality and evaluation of scientific research, as they were adjusted according to their observations and arrival to their final form. In order to ascertain the comprehension and clarity of the questionnaire and to know its credibility and validity, where the researchers relied on (Cronbach's alpha) because it reflects the level of cohesion and interrelation between the paragraphs of the questionnaire, according to (George \& Mallery 2003), the basic rules of the Cronbach's alpha are as follows: 
INTERNATIONAL JOURNAL OF ACADEMIC RESEARCH IN BUSINESS AND SOCIAL SCIENCES

Vol. 9, No. 3, March, 2019, E-ISSN: 222 2-6990 @ 2019 HRMARS

Table 3: illustrates the basic rules of the Cronbach's alpha coefficient

\begin{tabular}{|c|c|}
\hline The ratio & the degree \\
\hline .9 & Excellent \\
\hline .8 & good \\
\hline .7 & Acceptable \\
\hline .6 & Weak \\
\hline .5 & Very weak \\
\hline
\end{tabular}

Isaac and Michael (1995) mention that the alpha test sample would be useful if it was between 1030 and by test Cronbach's Alpha results were as follows:

Table 4: illustrates Cronbach's alpha test

\begin{tabular}{|c|c|c|}
\hline variable & No & Cronbach's Alpha \\
\hline Quality of facilities & 30 & .788 \\
\hline Level of qualification & 30 & .902 \\
\hline $\begin{array}{c}\text { Ease of } \\
\text { communication }\end{array}$ & 30 & .886 \\
\hline
\end{tabular}

According to the results of the test, the degree of all the axes of the questionnaire was positive, the results ranged between acceptable and good and excellent, and this indicates that there is consistency between the paragraphs so can rely on the questionnaire and achieve the goal of research.

\section{Normal Distribution of Data}

To find out whether the data in the questionnaire follow normal distribution or not, the researchers relied on (Kolmogorov-Smirnov Test) and reached the test to the following:

Table 5: shows the normal distribution test

\begin{tabular}{|c|c|}
\hline variable & Sig. \\
\hline Quality of facilities & 0.432 \\
\hline Level of qualification & 0.544 \\
\hline Ease of \\
communication
\end{tabular}

According to the previous table, the probability value of sig. For all variables is greater than (0.05). According to this result, the data can be said to follow normal distribution. 
INTERNATIONAL JOURNAL OF ACADEMIC RESEARCH IN BUSINESS AND SOCIAL SCIENCES Vol. 9, No. 3, March, 2019, E-ISSN: 222 2-6990 ¿ 2019 HRMARS

Table 6: shows the personal data of the research sample

\begin{tabular}{|c|c|c|}
\hline variable & the number & Percentage \\
\hline \multicolumn{3}{|c|}{ Gender } \\
\hline Male & 296 & $47 \%$ \\
\hline female & 338 & $53 \%$ \\
\hline \multicolumn{2}{|c|}{ Age } \\
\hline From 18 to less than 25 years & 396 & $62 \%$ \\
\hline From 25 to less than 40 years & 138 & $22 \%$ \\
\hline From 40 to less than 50 years & 79 & $13 \%$ \\
\hline 50 years and over & 21 & $3 \%$ \\
\hline \multicolumn{2}{|c|}{ Specialization } \\
\hline literary & 422 & $67 \%$ \\
\hline scientific & 212 & $33 \%$ \\
\hline Secondary & Scientific level & $10 \%$ \\
\hline BA & 64 & $64 \%$ \\
\hline M.A. & 407 & $18 \%$ \\
\hline Ph.D. & 114 & $8 \%$ \\
\hline
\end{tabular}

Table 6 shows that there are many differences between the research sample according to gender, age, specialization, and scientific level. This indicates that the diversity of the answers and this helps to get the best results.

\section{Analysis of Results}

Table 7: shows the analysis of the items of quality of the facilities

\begin{tabular}{|l|c|c|c|c|c|}
\hline \multicolumn{1}{|c|}{ the items of quality of the facilities } & mean & $\begin{array}{c}\text { Standard } \\
\text { deviation } \\
\text { s }\end{array}$ & $\begin{array}{c}\text { Big, very } \\
\text { big }\end{array}$ & $\begin{array}{c}\text { The } \\
\text { mean }\end{array}$ & $\begin{array}{c}\text { Little, } \\
\text { very } \\
\text { little }\end{array}$ \\
\hline $\begin{array}{l}\text { There is a medical clinic at the university to } \\
\text { provide student health services. }\end{array}$ & 2.33 & 1.346 & 37.2 & 24.1 & 38.7 \\
\hline $\begin{array}{l}\text { The classrooms are of a high standard of } \\
\text { equipment and cleanliness. }\end{array}$ & 2.95 & 1.237 & 56.7 & 35.4 & 7.9 \\
\hline $\begin{array}{l}\text { There are signboards that make it easy for } \\
\text { students to access all university facilities. }\end{array}$ & 3.74 & 0.721 & 71.6 & 22.3 & 6.1 \\
\hline $\begin{array}{l}\text { There are playgrounds and spaces to entertain } \\
\text { students. }\end{array}$ & 3.12 & 0.923 & 63 & 31.7 & 5.3 \\
\hline $\begin{array}{l}\text { There are of special facilities for students with } \\
\text { special needs. }\end{array}$ & 2.83 & 1.433 & 33.3 & 19.4 & 47.3 \\
\hline \multicolumn{1}{|c|}{ The total } & $\mathbf{2 . 9 9}$ & $\mathbf{1 . 1 3 2}$ & $\mathbf{5 2 . 3 6}$ & $\mathbf{2 6 . 5 8}$ & $\mathbf{2 1 . 0 6}$ \\
\hline
\end{tabular}


INTERNATIONAL JOURNAL OF ACADEMIC RESEARCH IN BUSINESS AND SOCIAL SCIENCES

Vol. 9, No. 3, March, 2019, E-ISSN: 222 2-6990 @ 2019 HRMARS

According to the previous table, it is clear that the research sample is the most approved by a very large percentage. This indicates that the facilities of the university are highly satisfactory to the research community. The mean for this paragraph was 2.99 , where the ratio ranged from 2.33 to paragraph 1 (There is a medical clinic at the university to provide student health services), 3.74 to paragraph 3 (There are signboards that make it easy for students to access all university facilities), While the value of the standard deviation was 1.132, with the highest ratio of standard deviation 1.433 for paragraph 5 (There are of special facilities for students with special needs), and the lowest ratio of 0.721 for paragraph 3 (There are signboards that make it easy for students to access all university facilities).

Table 8: shows the analysis of the items of level of qualification

\begin{tabular}{|l|c|c|c|c|c|}
\hline \multicolumn{1}{|c|}{ The items of level of qualification } & mean & $\begin{array}{c}\text { Standard } \\
\text { deviation } \\
\text { s }\end{array}$ & $\begin{array}{c}\text { Big, very } \\
\text { big }\end{array}$ & $\begin{array}{c}\text { The } \\
\text { mean }\end{array}$ & $\begin{array}{c}\text { Little, } \\
\text { very } \\
\text { little }\end{array}$ \\
\hline $\begin{array}{l}\text { There is a program to new students and } \\
\text { familiarize them with university laws. }\end{array}$ & 3.25 & 1.122 & 52.2 & 32.1 & 15.7 \\
\hline $\begin{array}{l}\text { Qualifying students through workshops and } \\
\text { seminars. }\end{array}$ & 3.73 & 0.906 & 66.1 & 31.5 & 2.4 \\
\hline $\begin{array}{l}\text { There are scientific conferences and students are } \\
\text { allowed to participate. }\end{array}$ & 3.25 & 0.914 & 44.2 & 41.6 & 14.2 \\
\hline $\begin{array}{l}\text { Students are required to make a curriculum } \\
\text { presentation at the end of each semester. }\end{array}$ & 2.39 & 1.232 & 20.1 & 33.3 & 46.6 \\
\hline $\begin{array}{l}\text { Giving material and moral incentives to } \\
\text { outstanding students. }\end{array}$ & 3.42 & 0.934 & 77.3 & 19.1 & 3.6 \\
\hline \multicolumn{1}{|c|}{ The total } & $\mathbf{3 . 2 0}$ & $\mathbf{1 . 0 2 1}$ & $\mathbf{5 1 . 9 8}$ & $\mathbf{3 1 . 5 2}$ & $\mathbf{1 6 . 5}$ \\
\hline
\end{tabular}

Table 8 shows that the majority of the respondents were very satisfied with the level of qualification at the university. The mathematical average of this item was 3.20. The ratio ranged from 2.39 to paragraph 4 (Students are required to make a curriculum presentation at the end of each semester), 3.73, to paragraph 2 (Qualifying students through workshops and seminars). While the value of the standard deviation was 1.021, with the highest percentage of standard deviation 1.232 for paragraph 4 (Students are required to make a curriculum presentation at the end of each semester) and the lowest percentage of 0.906 for paragraph 2 (Qualifying students through workshops and seminars). 
INTERNATIONAL JOURNAL OF ACADEMIC RESEARCH IN BUSINESS AND SOCIAL SCIENCES

Vol. 9, No. 3, March, 2019, E-ISSN: 2222-6990 @ 2019 HRMARS

Table 9: Shows the Analysis of the Items of Ease of Communication

\begin{tabular}{|l|l|l|l|l|l|}
\hline \multicolumn{1}{|c|}{ The items of ease of communication } & \multicolumn{1}{|c|}{ mean } & $\begin{array}{c}\text { Standard } \\
\text { deviation } \\
\text { s }\end{array}$ & $\begin{array}{c}\text { Big, very } \\
\text { big }\end{array}$ & $\begin{array}{c}\text { The } \\
\text { mean }\end{array}$ & $\begin{array}{c}\text { Little, } \\
\text { very } \\
\text { little }\end{array}$ \\
\hline Staff have a skill to communicate with students. & 4.55 & 0.732 & 88.1 & 9.3 & 2.6 \\
\hline $\begin{array}{l}\text { Easy access to the educational resources } \\
\text { provided by the university. }\end{array}$ & 3.77 & 0.792 & 63.6 & 21.1 & 15.3 \\
\hline $\begin{array}{l}\text { There is a quick response to students' queries } \\
\text { from staff and faculty members despite the } \\
\text { pressures of work. }\end{array}$ & 3.99 & 0.923 & 70.4 & 9.2 & 20.4 \\
\hline $\begin{array}{l}\text { There is an electronic portal for the students } \\
\text { through which they can know everything new in } \\
\text { the university. }\end{array}$ & 2.89 & 1.523 & 35.5 & 39.1 & 25.4 \\
\hline $\begin{array}{l}\text { Easy communication between faculty members } \\
\text { and staff in all departments. }\end{array}$ & 4.01 & 0.799 & 77.3 & 11.1 & 11.6 \\
\hline \multicolumn{1}{|c|}{ The total } & $\mathbf{3 . 8 4}$ & $\mathbf{0 . 9 5 3}$ & $\mathbf{6 6 . 9 8}$ & $\mathbf{1 7 . 9 6}$ & $\mathbf{1 5 . 0 6}$ \\
\hline
\end{tabular}

According to the previous table 9, the majority of the research sample is approved by a large and very large percentage. This indicates the ease of communication between the students and the rest of the university. Where the mean of the total number of paragraphs was 3.84, where the ratio ranged from 2.89 to paragraph 4 (There is an electronic portal for the students through which they can know everything new in the university), 4.55 for paragraph 1 (Staff have a skill to communicate with students) The value of the standard deviation of all the paragraphs is 0.953 , with the highest deviation of the standard deviation of 1.523 for paragraph 4 (There is an electronic portal for the students through which they can know everything new in the university) and the lowest ratio of 0.732 for paragraph 1 (Staff have a skill to communicate with students).

\section{Testing Hypotheses}

The first hypothesis: There is no statistically significant relationship between the quality of facilities within the University of Mohammed bin Ali Al-Sanussi and the quality of educational services.

Table 10: Pearson correlation coefficient between quality of facilities and quality of educational services

\begin{tabular}{|c|c|c|c|}
\hline \multicolumn{2}{|c|}{} & Quality of facilities & $\begin{array}{c}\text { Quality of educational } \\
\text { services }\end{array}$ \\
\hline \multirow{4}{*}{ Quality of facilities } & Pearson Correlation & 1 & $.866^{* *}$ \\
\cline { 2 - 4 } & Sig(2-tailed) & & .001 \\
\cline { 2 - 4 } & The number & 5 & 5 \\
\hline $\begin{array}{c}\text { Quality of educational } \\
\text { services. }\end{array}$ & Pearson Correlation & $.866^{* *}$ & 1 \\
\cline { 2 - 4 } & Sig (2-tailed) & .001 & 5 \\
\cline { 2 - 4 } & The number & 5 & \\
\hline
\end{tabular}

**. Correlation is significant at the 0.01 level (2-tailed). 
INTERNATIONAL JOURNAL OF ACADEMIC RESEARCH IN BUSINESS AND SOCIAL SCIENCES

Vol. 9, No. 3, March, 2019, E-ISSN: $2222-6990$ C 2019 HRMARS

The second hypothesis: There is no statistically significant relationship between the Level of qualification within the University of Mohammed bin Ali Al-Sanussi and the quality of educational services.

Table 11: Pearson correlation coefficient between Level of qualification and quality of educational services

\begin{tabular}{|c|c|c|c|}
\hline & & $\begin{array}{c}\text { Level of } \\
\text { qualification }\end{array}$ & $\begin{array}{c}\text { Quality of educational } \\
\text { services }\end{array}$ \\
\hline \multirow[t]{3}{*}{$\begin{array}{c}\text { Level of } \\
\text { qualification }\end{array}$} & $\begin{array}{c}\text { Pearson } \\
\text { Correlation }\end{array}$ & 1 & $.843 * *$ \\
\hline & Sig(2-tailed) & & .001 \\
\hline & The number & 5 & 5 \\
\hline \multirow{3}{*}{$\begin{array}{c}\text { Quality of } \\
\text { educational } \\
\text { services. }\end{array}$} & $\begin{array}{c}\text { Pearson } \\
\text { Correlation }\end{array}$ & $.843 * *$ & 1 \\
\hline & Sig (2-tailed) & .001 & \\
\hline & The number & 5 & 5 \\
\hline
\end{tabular}

**. Correlation is significant at the 0.01 level (2-tailed).

The third hypothesis: There is no statistically significant relationship between the ease of communication within the University of Mohammed bin Ali Al-Sanussi and the quality of educational services.

Table 12: Pearson Correlation Coefficient between Ease of Communication and Quality of Educational Services

\begin{tabular}{|c|c|c|c|}
\hline & & $\begin{array}{c}\text { ease of } \\
\text { communication }\end{array}$ & $\begin{array}{c}\text { Quality of educational } \\
\text { services }\end{array}$ \\
\hline \multirow[t]{3}{*}{$\begin{array}{c}\text { ease of } \\
\text { communication }\end{array}$} & $\begin{array}{c}\text { Pearson } \\
\text { Correlation }\end{array}$ & 1 & $.863 * *$ \\
\hline & Sig(2-tailed) & & .001 \\
\hline & The number & 5 & 5 \\
\hline \multirow{3}{*}{$\begin{array}{l}\text { Quality of } \\
\text { educational } \\
\text { services. }\end{array}$} & $\begin{array}{c}\text { Pearson } \\
\text { Correlation }\end{array}$ & $.863^{* *}$ & 1 \\
\hline & Sig (2-tailed) & .001 & \\
\hline & The number & 5 & 5 \\
\hline
\end{tabular}

**. Correlation is significant at the 0.01 level (2-tailed).

According to previous tables 10-11-12, and the test of the relationship between the variables in the research, the researchers found that both the quality of the facilities and the level of qualification and ease of communication have a statistical significance relationship with the quality of educational services at the University of Mohammed bin Ali Sanussi. This relationship is very strong and this negates the validity of the hypotheses and proves that there is a relationship between the variables. 


\section{Results and Recommendations \\ Results:}

- The classrooms in the university are equipped with a good standard, clean and always cared for them, easy access to any hall or section of the university through the paintings, and there are some sports activities for students, staff and faculty members.

- Medical services at the university are reasonable from the point of view of the university's members. The university lacks facilities for people with special needs, and there is a private parking station.

- There are programs to qualify students at the beginning of each semester and introduce students to all the laws in the university. After each period, the university will conduct seminars, workshops and seasonal cultural activities that benefit both the staff and the students.

- Outstanding students enjoy some incentives such as obtaining a teaching function at the university. The university lacks to compel students to make a presentation of some of the subjects studied at the end of the semester.

- The staff and faculty members communicate with the students on a regular basis and answer all their queries. Students can also use the library and take all the books or files they need to help them in their study journey, while there is one central library in the college complex as well as another library at the Center for Research and Scientific Studies.

- The college complex has one common office for heads of scientific departments in the colleges, and there is an activity hall containing furniture and computers for use by students and faculty members in covering the courses.

- Students, faculty members and staff communicate with the general administration of the University easily and conveniently, through delegates and administrative correspondents; despite its presence in another independent complex.

\section{Contribution}

The importance of this paper comes from the importance of the quality of educational services within universities, institutes and research centers, as there is no study on the quality educational of the services of the University of Mohammed bin Ali Al-Sanussi.

And that the university is considered one of the largest universities in the State of Libya, and the results of this research may be useful and important for the rest of the Libyan universities and can be used to develop the quality of services in all Libyan universities.

Due to the specificity of the university and its various specializations, it is witnessing the influx of students and faculty members from all over Libya. Therefore, the educational services provided to them must be of high quality and efficiency. This paper is distinguished from its predecessors because researchers are interested in quality programs, which will contribute to the enrichment of scientific knowledge, and the consolidation of the principle of spreading the culture of quality among students, staff and faculty members and to strengthen communication relations between them, and create a good atmosphere is characterized by teamwork. 


\section{Recommendations}

- Work on the development of health services at the university, and must be there are facilities for people with special needs.

- The need to increase the training of students by involving them more in scientific conferences and workshops so that they can stand up and speak to the public easily.

- Faculty members must compel students to make the researches and presentations of some materials and explain them in front of students periodically as its important in developing students' skills and abilities.

- Work on establishing a system for the university and obligating students to open an account into it so that the student can download all the models of his own, and can also know the dates of exams and the result and everything related to the study.

- The need to provide a library of books and research, and be independent and especially each department or college alone. Furthermore, preparation of halls for use in forums and scientific and cultural activities.

\section{References}

Abdelkader, M. N. (2016). Measuring students' awareness of the quality of educational service at the branches of Taif University. Journal of the researcher. No. 16. pp. 167-181.

Ajmi, N. B., \& Al-Tuwaijri, F. B. (2016). The quality of educational services in Saudi universities in the light of a developed standard: Imam Muhammad bin Saud Islamic University model. Arab Journal for Quality Assurance of University Education. Volume IX. No. 25. pp. 135-163.

Borges, L. F., Santos, C. K., \& Leal, E. (2014). Quality in educational service: Expectations versus performance in the accounting undergraduate course. European Scientific Journal, 10(1).

Ereş, F., \& Clothey, R. (2013). Perceived Service Quality in Schools of Education: A Comparative Study between Drexel University and Gazi University. American International Journal of Social Science.October.Vol.2 No. 7.

George. D., \& Mallery, P. (2003) SPSS for windows step by step: A sample Guide \& reference Boston; Allyn \& Bacon.

Gholami, A., Gazerani, A., Behfar, K., Asghari, A., Mohammadzadeh, H., Samadi, A., \& Foroozanfar, Z. (2014).Quality Evaluation of Educational Services Gap in Neyshabur Faculty of Medical Sciences Based on Service Quality Scale. Shiraz E-Med. 15(3). PP 2-7.

Gilavand, A., Fatahiasl, J., \& Majd, R. M. (2017). Evaluating the Quality of Educational Services from the Viewpoints of Radiology Students of Ahvaz Jundishapur University of Medical Sciences, in Southwest of Iran. Middle East Journal of Family Medicine, 7(10), 187-192.

Hudaibi, D., \& Qudhwa, H. A. (2009). The quality of educational services in the Faculty of Education of the view of students of scientific departments. Arab Journal for Quality Assurance of University Education. Issue 4. pp. 92-108.

Isaac, S., \& Michael, W. B. (1995). Handbook in Research and Evaluation. San Diedo, C. A: Educational and Industrial Training Services.

Krejcie, R. V., \& Morgan, D. W. (1970). Determining Sample Size for Research Activities. Educational and Psychological Measurement, 30, 607-610. 
Salhi, A. S., \& Jaballah, J. A. (2016). Measuring the quality of educational services at the Faculty of Economics and Political Science at the University of Misurata from the point of view of students. Journal of Economics and Business Studies. Dec. Volume 5. Issue 2. pp. 60-75.

Shuaibi, M., \& Al-Shahrani, S. (2014). Assessment of the quality of educational services at King Khalid University from the perspective of students. Journal of Dhamar University for Studies and Research. January. No. 19. pp. 317-346.

Zaki, H. (2016). The impact of applying the quality of educational services in the light of the new university reform - A case study of the Taher Moulay University of Saida.. PhD thesis. Marketing Services. University of Abu Bakr Belqayd. Talsman. Algeria. 